\title{
The Inversion Method in Measuring Noise Emitted by Machines in Opencast Mines of Rock Material
}

\author{
Dariusz Pleban \\ Central Institute for Labour Protection - National Research Institute (CIOP-PIB), Poland
}

\section{Janusz Piechowicz}

AGH University of Science and Technology, Kraków, Poland

Krzysztof Kosała

\begin{abstract}
Central Institute for Labour Protection - National Research Institute (CIOP-PIB), Poland AGH University of Science and Technology, Kraków, Poland
\end{abstract}

The inversion method was used to test vibroacoustic processes in large-size machines used in opencast mines of rock material. When this method is used, the tested machine is replaced with a set of substitute sources, whose acoustic parameters are determined on the basis of sound pressure levels and phase shift angles of acoustic signals, measured with an array of 24 microphones. This article presents test results of a combine unit comprising a crusher and a vibrating sieve, for which an acoustic model of 7 substitute sources was developed with the inversion method.

noise machines opencast mines inversion method substitute sources

\section{INTRODUCTION}

Analyses of working conditions in mining establishments showed that hazardous and harmful occupational conditions there include the following groups of factors: physical, chemical, biological and psychophysical [1]. In the first group of these factors, in addition to dust, mechanical vibrations, light and electromagnetic fields, noise poses a significant risk. $A$-weighted sound pressure levels at workstations in underground mining establishments exceed $85 \mathrm{~dB}[2,3]$. This value is also exceeded in opencast mining $[4,5]$.
According to Poland's State Mining Authority, 226 mining establishments (including 101 opencast ones) operated in Poland in 2011, employing over 148000 workers (including over 15000 workers in opencast mines) [6]. About 26000 workers were exposed to noise hazard [1], and the significance of this problem is evidenced by the number of mining workers who were found to suffer from an occupational disease manifested in a permanent loss of hearing. In 2006-2010, 354 mining workers were found to be affected by this occupational disease, and 71 cases of permanent loss of hearing were recorded in $2010[1,7]$.

\footnotetext{
This paper was based on the results of a research task carried out within the scope of the second stage of the National Programme "Improvement of safety and working conditions" partly supported in 2011-2013 - within the scope of state services-by the Ministry of Labour and Social Policy. The Central Institute for Labour Protection - National Research Institute is the Programme's main co-ordinator.

The original program for multichannel recording and data analysis was developed thanks to a grant from the Ministry of Science and Higher Education N N504 342536.

The authors wish to thank Dr Lesław Stryczniewicz of the Department of Mechanics and Vibroacoustics of the AGH University of Science and Technology for discussing the research results.

Correspondence should be sent to Dariusz Pleban, CIOP-PIB, ul. Czerniakowska 16, 00-701 Warszawa, Poland. E-mail: daple@ ciop.pl.
} 
As already mentioned, also in opencast mines, noise is one of the main harmful factors, and it is a threat to the external environment, especially when mining works are carried out near residential areas or nature reserves. $A$-weighted sound pressure levels measured in Polish opencast mines in many cases reach values of up to $105 \mathrm{~dB}$, and particularly noisy machines include combine units, crushers and vibrating sieves $[8,9]$.

Therefore, it is necessary to protect workers of opencast mines against noise hazards. However, to develop effective technical measures protecting against noise, it is necessary to first measure noise emitted by mining machines. Therefore, this paper presents a method of measuring noise emitted by machines used in opencast mines of rock material. This method is applied for in-situ conditions and uses the principles of the inversion method.

\section{INVERSION METHOD}

In recent years, inversion methods have become increasingly commonly used in various fields of science and life, including geophysics, medicine and mechanics. In mechanics, inversion methods are used, e.g., in the theory of elasticity, theory of plasticity and in vibroacoustics [10]. Z. Engel initiated several applications of the inversion method in vibroacoustics [10, 11, 12, 13]. According to Engel, Engel and Kosała, the principle of using the inversion method in the fields mentioned in section 1 consists in determining the parameters of a model by manipulating

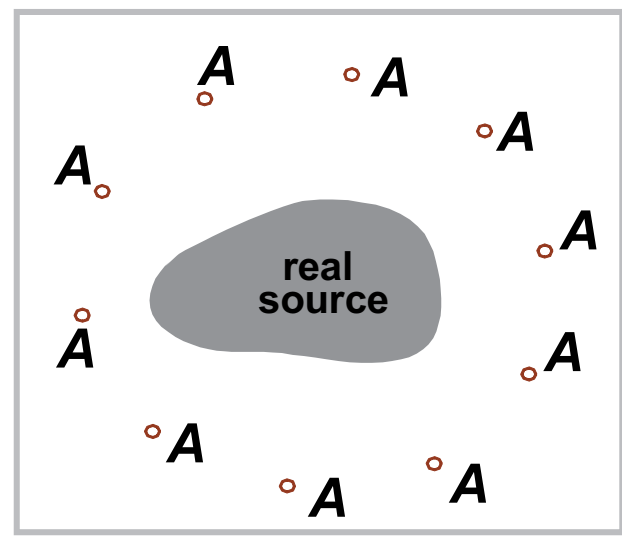

recorded data [10]. This paper did that to determine substitute acoustic models for a machine.

By modelling the process of vibroacoustic energy radiation by the source to the receiver, when the true value of sound pressure at the measuring points is known, the propagation path model can be reversed; thus the parameters of the sound source can be determined. Figure 1 shows the inversion method used to determine parameters of a model.

Sound pressure at the observation points marked in Figure 1 as $A$ can be determined on the basis of the inversion method with Equation 1 $[10,11,12,13]$ :

$$
\pi=G \alpha+e,
$$

where $\pi=m$-dimensional vector of the measured complex sound pressure amplitudes at observation points; $\alpha=n$-dimensional vector of complex parameter values of model sources; $G=m \times n$ matrix defining the complex sound pressure value at observation points, based on parameters of substitute sources determined from the properties of the adopted emission model; $e=m$-dimensional error vector. To minimize the error vector $e$, the parameters of individual substitute sources of the model should be matched.

To determine acoustic parameters of substitute sources, it is necessary to determine both the sound pressure amplitude distribution around the modelled machine, and the distribution of phase shifts angles between acoustic signals. The inversion method makes it possible to identify sources of noise in the entire combined unit of machines

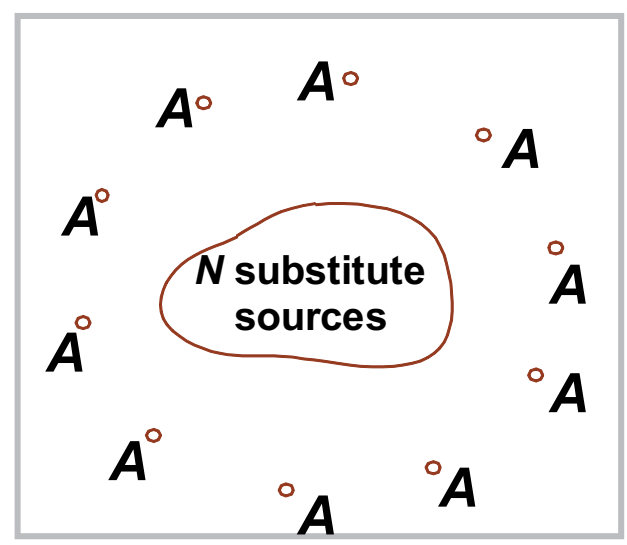

Figure 1. Diagram of determining parameters of a model with the inversion method [11]. 
and assign them appropriate values of sound power. Knowing the acoustic activity of sources helps in taking appropriate measures to prevent noise.

\section{METHOD AND TEST STAND}

As mentioned in section 2, using the inversion method to determine the acoustic parameters of machines requires knowing the distribution of the parameters of the acoustic field in the vicinity of the machine. This is appropriate in laboratory conditions and in situ. The test item was a combine unit consisting of a ZKDU 120/130 crusher $^{1}$ (Zanam Legmet, Poland) and a vibrating aggregate sieve, located in an opencast limestone mine (Figure 2). The crusher was $4.76 \mathrm{~m}$ wide, $12.28 \mathrm{~m}$ long and $4.42 \mathrm{~m}$ high. A mobile loader that fed stone into the top hopper of the crusher emitted noise, too. The workstations involved controlling the operating unit and feeding the hopper with stone. The workers and supervisors were exposed to excessive noise emitted by the entire combine unit. Table 1 summarizes the sound pressure levels measured with a SVAN 945A (SVANTEK, Poland) sound level meter at the operator's workstation.

Measuring noise involved

- creating an acoustic model of the tested unit and breaking it down into substitute sound sources;

- arranging 24 measuring microphones around the machine and assigning them spatial coordinates (Figure 3);

- recording sound pressure levels and phase shift angles of acoustic signals at measurement points;

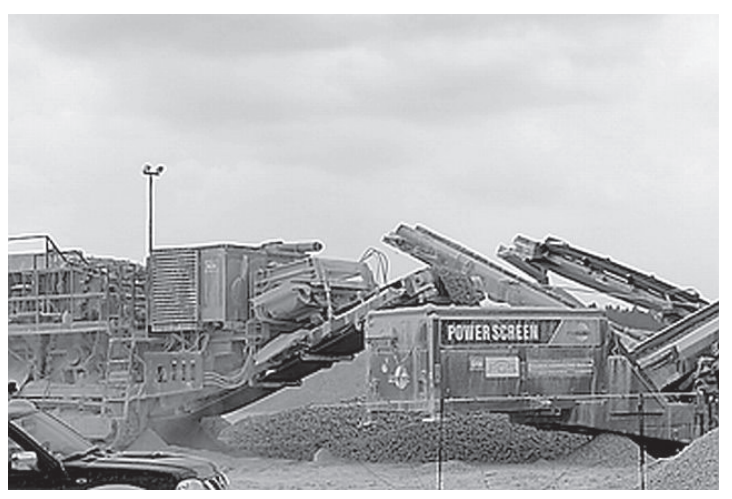

Figure 2. Limestone processing combine unit: crusher and vibrating sieve.

- analysing measurement results and determining sound power levels of substitute sources.

The measuring circuit was built on the basis of a National Instruments (USA) PXI-1042Q chassis equipped with three synchronized 8-channel measurement cards NI-PXI-4472B, to which 24 matrix $1 / 4$ " microphones were connected (GRAS, Denmark, type 40PQ and Brüel \& Kjær, Denmark, type 4958). Figure 4 illustrates the location of the microphones. A power generator located $\sim 100 \mathrm{~m}$ away from the test item powered the devices; its operation did not affect the acoustic background. Measurements were made for three modes of machine operation:

- limestone crushing and handling by a conveyor for sieving onto the vibrating sieve;

- loading the hopper with the loader, with the entire combine unit in operation;

- idling, no crushing or sieving.

The results of the measurements (values of sound pressure and phase angles for each microphone) were recorded directly onto the hard drive

TABLE 1. Sound Pressure Level in Octave Frequency Bands $f$ and Equivalent $A$-Weighted Sound Pressure Level at a Crusher Operator's Workstation

\begin{tabular}{lccccccccc}
\hline & \multicolumn{7}{c}{ Sound Pressure Level (dB) } \\
\cline { 2 - 9 } Mode & $\boldsymbol{f}(\mathbf{H z})$ & $\mathbf{1 2 5}$ & $\mathbf{2 5 0}$ & $\mathbf{5 0 0}$ & $\mathbf{1 0 0 0}$ & $\mathbf{2 0 0 0}$ & $\mathbf{4 0 0 0}$ & $\mathbf{8 0 0 0}$ & $\boldsymbol{L}_{\text {Aeq }}$ \\
\hline Crushing & & 99.7 & 101.6 & 96.3 & 96.3 & 94.7 & 90.3 & 82.0 & 101.3 \\
Crushing and loading & & 100.8 & 100.8 & 97.7 & 100.9 & 97.7 & 93.4 & 85.9 & 104.3 \\
\hline
\end{tabular}

Notes. $L_{\text {Aeq }}=$ equivalent $A$-weighted sound pressure level $(\mathrm{dB})$

\footnotetext{
${ }^{1}$ http://www.zanam-legmet.pl/index.php?option=com_content\&view=article\&catid=915\%3Akruszarki\&id=220\%3Azkdu-120130\&lang=en
} 


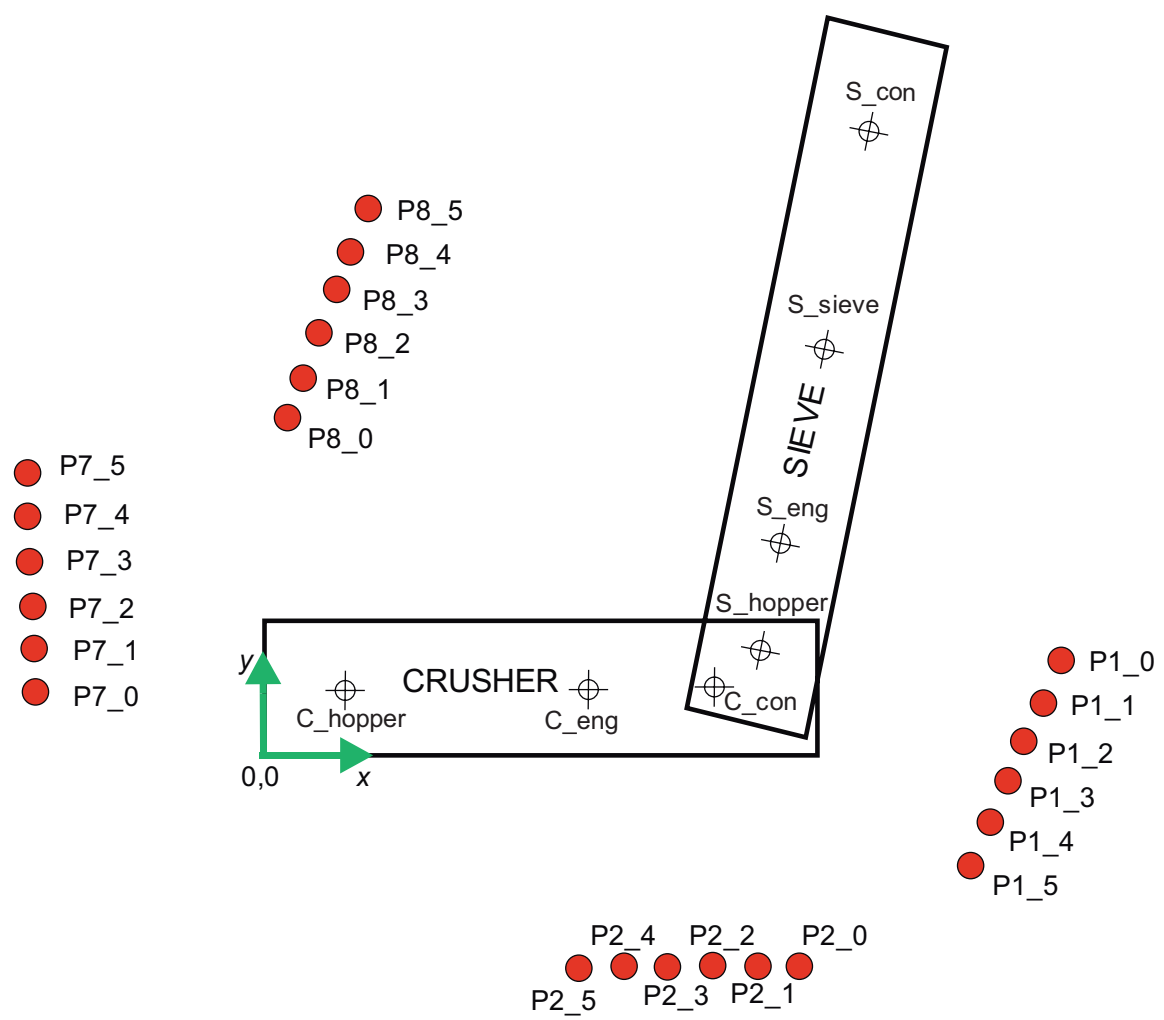

Figure 3. Distribution of measurement points around the tested combine unit of the crusher and the vibrating sieve. Notes. C_hopper = crusher hopper, C_eng = crusher engine, C_con = crusher conveyor, S_hopper = sieve hopper, S_eng = sieve engine, S_sieve = sieve, S_con = sieve conveyor; P1_0...P1_5, P2_0...P2_5, P7_0...P7_5, P8_0...P8_5 = measurement points.

of the NI PXI-1042Q chassis, simultaneously in 24 measurement channels in the form of TDMS files, which is a fast and lossless method of saving data.

To measure sound and to process data, two virtual tools in the form of original software packages were developed in house in the LabVIEW environment: a multichannel recorder and a spectral analyser. Calculations were performed on the basis of the values of sound pressure levels from 24 measuring points in the vicinity of the combine unit, taking into account phase shift angles of signals recorded between different microphones and the co-ordinates of the microphones. The saved files were analysed with a resolution of $1 \mathrm{~Hz}$ in the frequency range from 20 to $12500 \mathrm{~Hz}$.

The position of each substitute source in the acoustic field is defined by its co-ordinates in the reference system. The discrepancy between cal- culated and measured values is defined by the error function:

$$
e=p^{\mathrm{calc}}-p^{\text {meas }},
$$

where $e=$ error vector $(\mathrm{Pa}), p^{\text {calc }}=$ calculated sound pressure $(\mathrm{Pa}), p^{\text {meas }}=$ measured sound

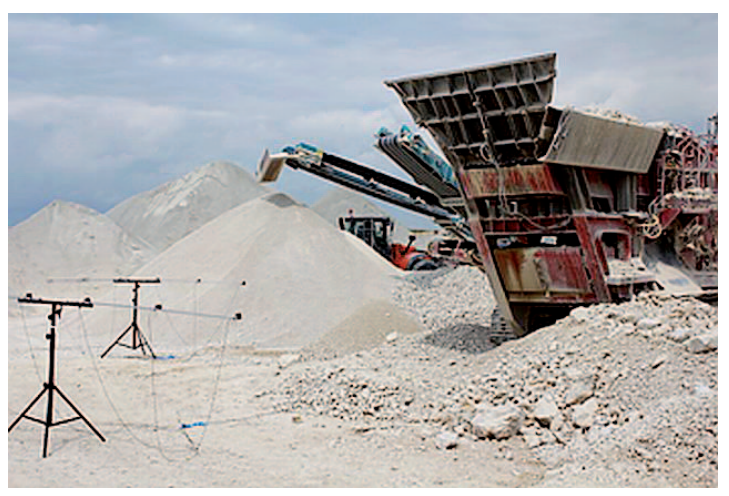

Figure 4. Arrangement of measuring microphones around the crusher. 
pressure $(\mathrm{Pa})$. For a correct determination of the acoustic parameters of substitute sources, the value of the error function $e$ tends to 0 .

The error vector $e=\left[e_{1}, \ldots, e_{a}, \ldots, e_{A}\right]^{T}$ can be entered for observation points $A$. The error vector can be minimized by controlling the values of the component sound power sources involved. The criterion of error between the predicted and measured solution can be represented by the smallest sum of squares. This problem can also be solved with the Tikhonov regularization method, which was used in determining the sound power of the crusher/sieve components.

\section{RESULTS}

Acoustic measurements determined the distributions of sound pressure values at 24 measuring points. The sound power of the source was determined by reversing the modelled sound propagation path from the source to the observation points (Figure 5). Thus, by using the inversion method, the real sound source was replaced with a set of substitute sources, and then acoustic parameters of these sources were simulated to achieve the distribution of the acoustic field produced by this set as consistent as possible with the distribution of the acoustic field around the real source.

A combine unit was modelled with seven substitute sources: three for the crusher (hopper, engine and conveyor) and four for the sieve (hopper, engine, sieve and conveyor) (Figure 3 ).

Figures 6-8 show sound power spectra of substitute sources determined with the inversion method in one-third-octave bands with centre frequencies from 50 to $12500 \mathrm{~Hz}$ for three operation modes: crushing (Figure 6), loading (Figure 7) and idling (Figure 8).

Figure 9 presents narrow-band sound power spectra in the frequency range from 20 to $12420 \mathrm{~Hz}$ of selected substitute sources of the combine unit for various operation modes.

The results show that most of the sound power emitted by the tested combine unit consisting of a crusher and a sieve is within the frequency range up to $2500 \mathrm{~Hz}$ for each operation mode. As

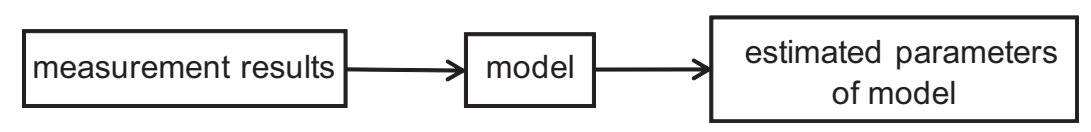

Figure 5. Modelling inversion.

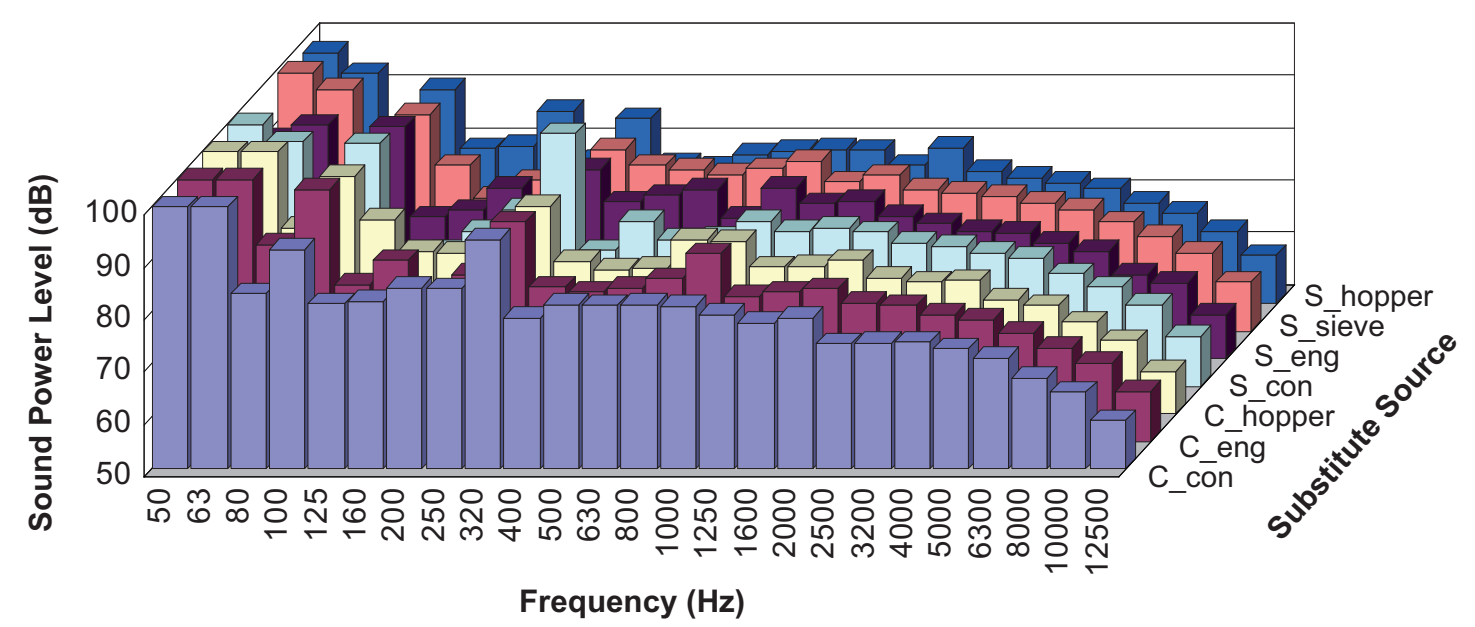

Figure 6. Sound power levels of substitute sources for one-third-octave bands for the crushing mode. Notes. C_con = crusher conveyor, C_eng = crusher engine, C_hopper = crusher hopper, S_con = sieve conveyor, $\mathbf{S} \_$eng $=$sieve engine, S_sieve = sieve, S_hopper = sieve hopper. 


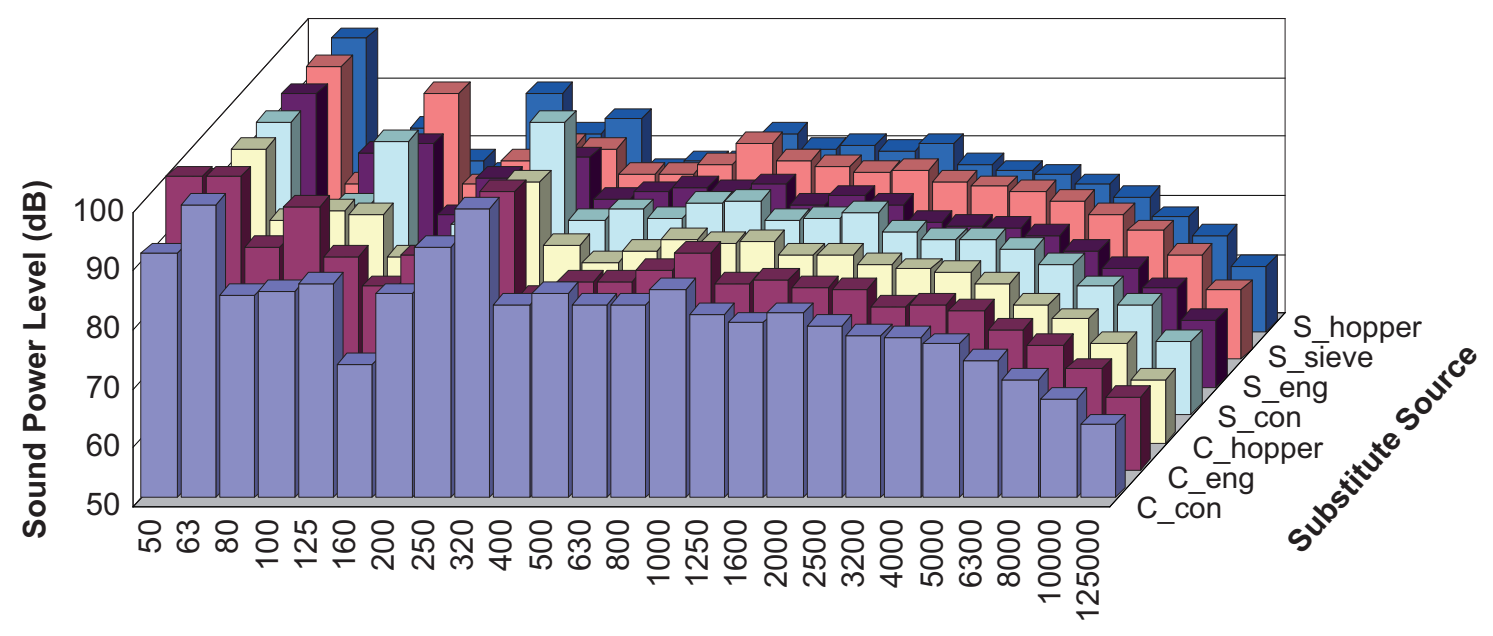

Frequency $(\mathrm{Hz})$

Figure 7. Sound power levels of substitute sources for one-third-octave bands for the loading mode. Notes. C_con = crusher conveyor, C_eng = crusher engine, C_hopper = crusher hopper, S_con = sieve conveyor, S_eng = sieve engine, S_sieve = sieve, S_hopper = sieve hopper.

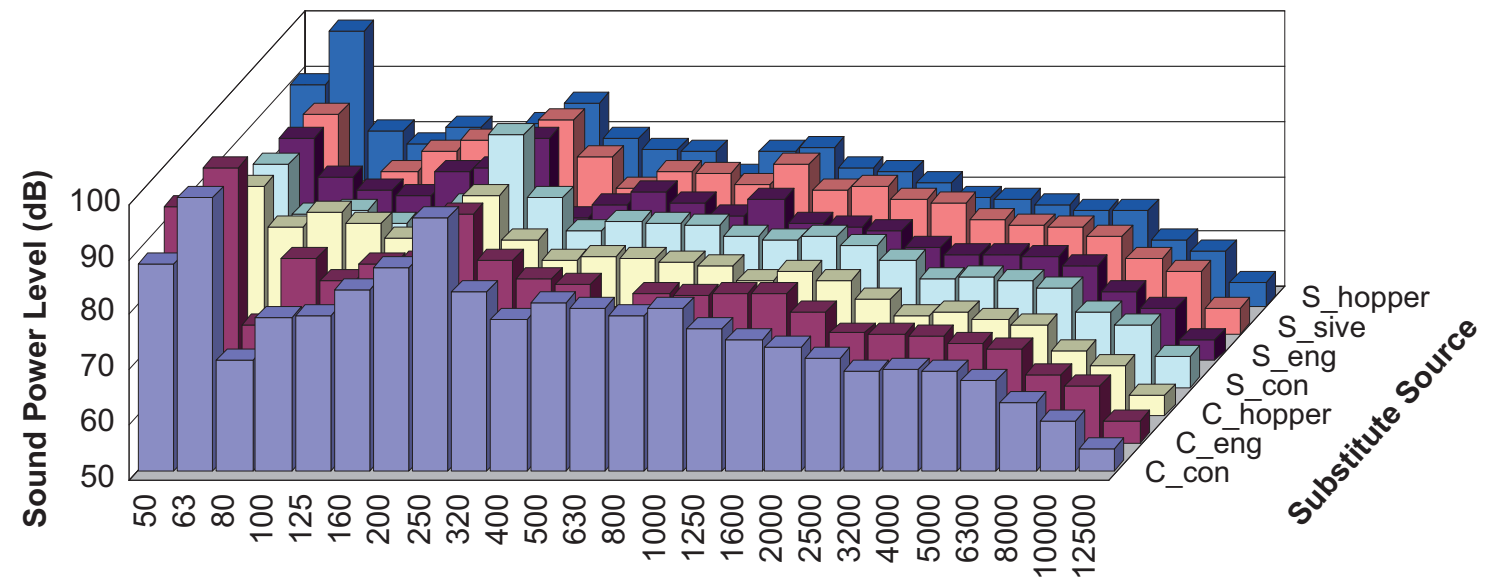

Frequency $(\mathrm{Hz})$

Figure 8. Sound power levels of substitute sources for one-third-octave bands for the idling mode. Notes. C_con = crusher conveyor, C_eng = crusher engine, C_hopper = crusher hopper, S_con = sieve conveyor, S_eng = sieve engine, S_sieve = sieve, S_hopper = sieve hopper.

expected, the lowest sound power level is typical for the idling mode. In this case, the highest sound power values determined are 102.2 and $100.4 \mathrm{~dB}$ for the substitute sources of the crusher and sieve, and the crusher engine, respectively, in the one-third-octave band with a centre frequency of $63 \mathrm{~Hz}$.

In the loading mode, the highest sound power levels of substitute sources are as follows:

- $110.4 \mathrm{~dB}$ (crusher engine), $108.2 \mathrm{~dB}$ (crusher hopper), $101.3 \mathrm{~dB}$ (sieve conveyor and crusher conveyor) in the one-third-octave band with a centre frequency of $50 \mathrm{~Hz}$;

- $105.9 \mathrm{~dB}$ (crusher engine), $103 \mathrm{~dB}$ (crusher conveyor), $101.8 \mathrm{~dB}$ (crusher hopper) in the one-third-octave band with a centre frequency of $63 \mathrm{~Hz}$.

Crushing is the loudest mode of the combine unit; during crushing, the highest values of sound power level exceed $100 \mathrm{~dB}$ for each substitute source in the one-third-octave band with a centre frequency of $63 \mathrm{~Hz}$. 
(a)

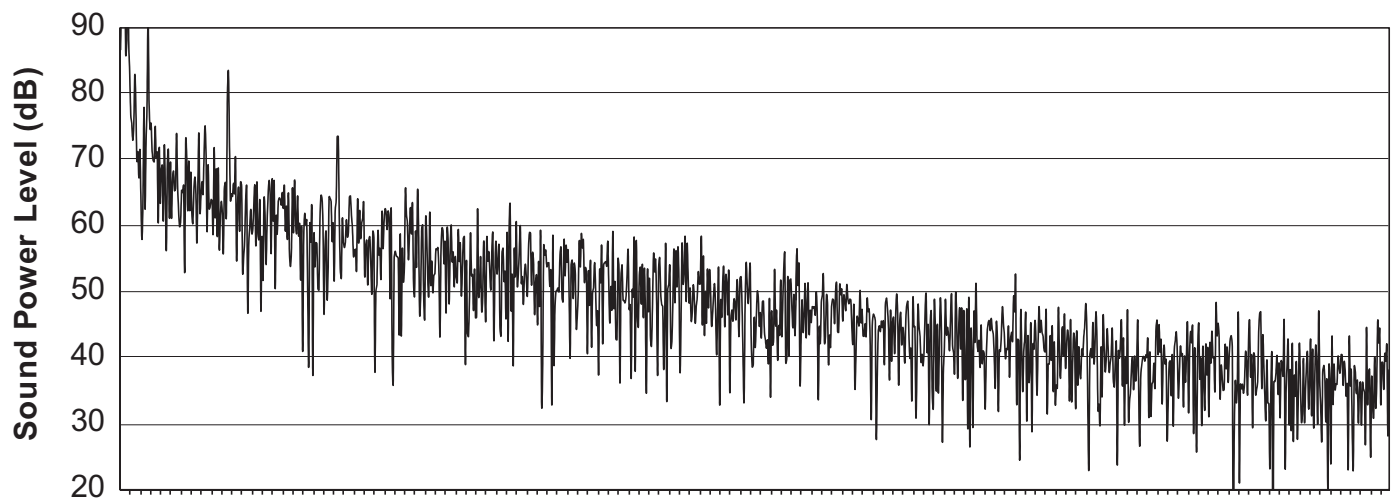

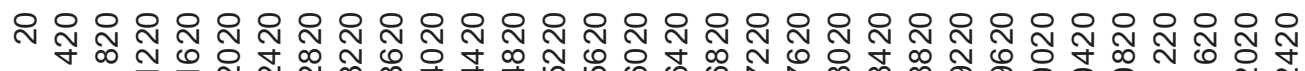

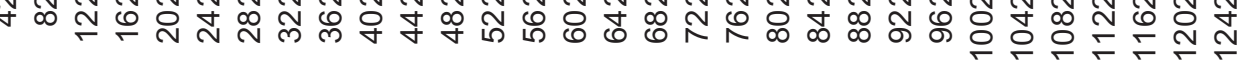

Frequency $(\mathrm{Hz})$

(b)

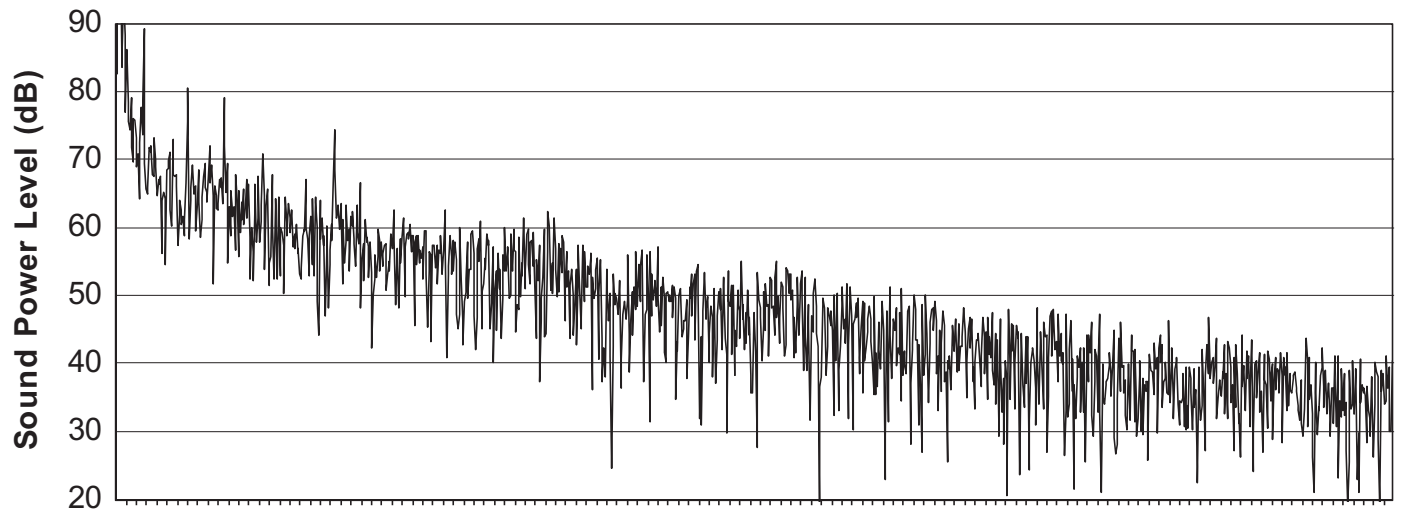

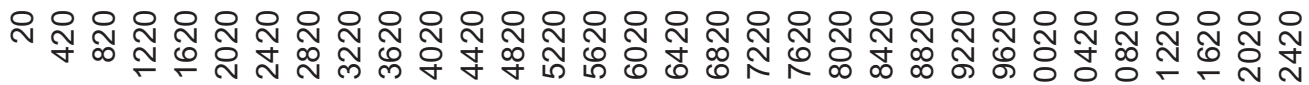

Frequency $(\mathrm{Hz})$

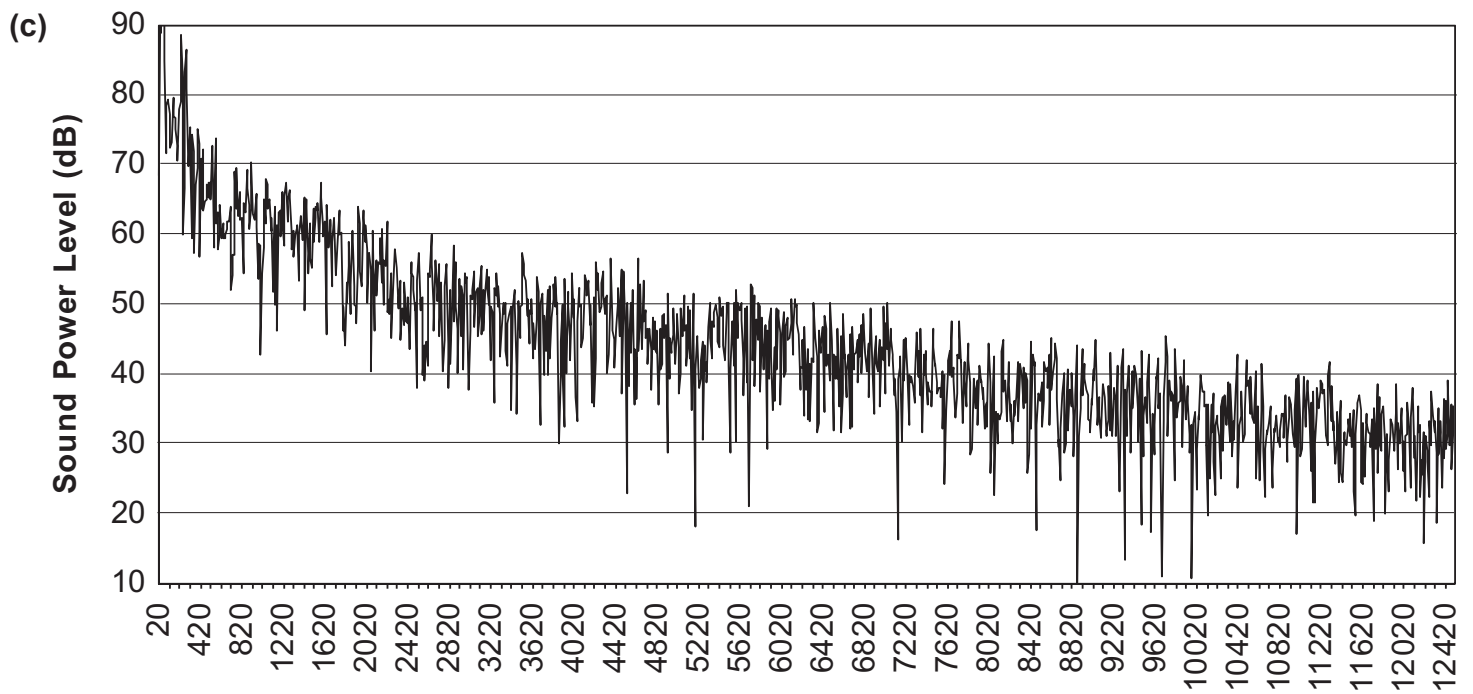

\section{Frequency $(\mathrm{Hz})$}

Figure 9. Narrow-band sound power spectra of selected substitute sources of the crusher and sieve combined unit: (a) crusher engine during loading, (b) crusher hopper during loading, (c) idling crusher engine, (d) idling sieve engine, (e) sieve sieve during crushing, (f) sieve conveyor during crushing. 
(d)

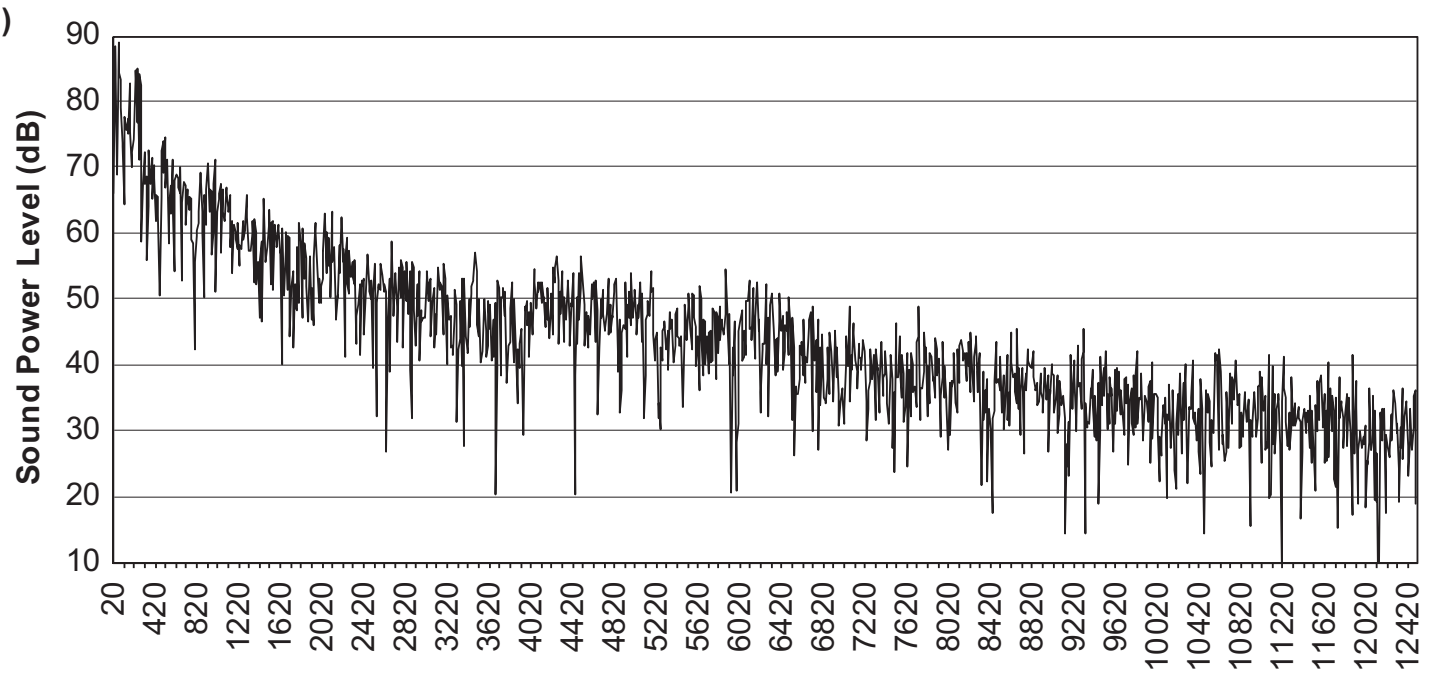

Frequency (Hz)

(e)

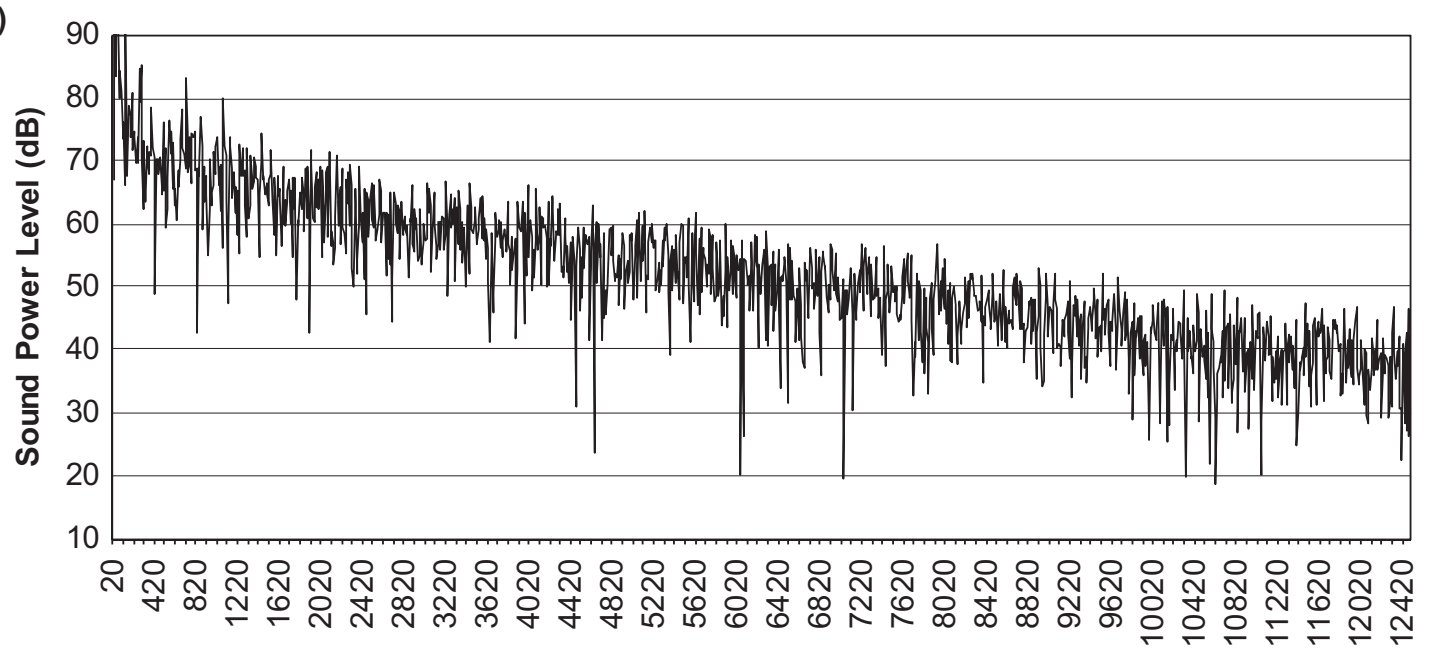

Frequency $(\mathrm{Hz})$

(f)

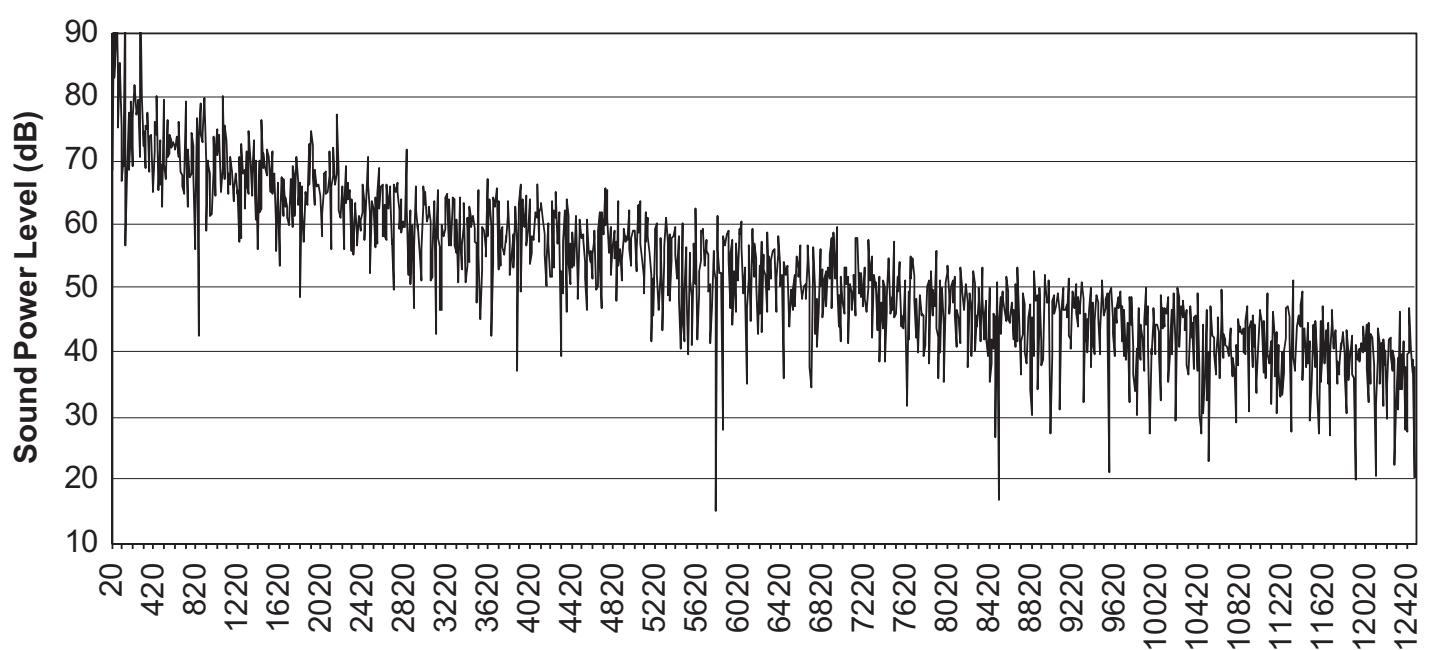

Frequency $(\mathrm{Hz})$

Figure 9. (continued) 


\section{CONCLUSIONS}

Previous experience of the authors in using the inversion method for testing noise and vibration processes was related to the research activities carried out under laboratory conditions or in confined areas $[14,15,16,17,18,19,20,21,22,23$, 24] and allowed for the use of the inversion method for testing machines for which the measuring environment is open space. A method was developed for testing noise emitted by machines used in opencast mines of rock material, which by using the inversion method makes it possible to determine acoustic parameters of substitute sources, which are an acoustic model of the tested machine.

The combine unit (comprising a crusher and a sieve) tests were carried out in an opencast mine. An analysis of the results showed that the inversion method can be used in-situ in open space conditions. The results also confirmed the problem of high exposure to noise of workers in an opencast rock material mine; the measured $A$-weighted sound pressure levels at the workstations of a crusher operator exceed $100 \mathrm{~dB}$.

The combine unit tests carried out with the inversion method showed that

- it was sufficient to determine seven substitute sources of acoustic parameters to develop a substitute acoustic model of the tested combine unit;

- it is sufficient to use a system of 24 measuring microphones to record sound pressure levels and phase shift angles of acoustic signals emitted by large-size machines (i.e., with the length, width and height exceeding 12, 4.5 and $4 \mathrm{~m}$, respectively) to determine a substitute acoustic model;

- the data obtained from tests on the location of substitute sources and sound power levels of these sources are a basis for developing a mathematical and computer model of a noise protection system.

The inversion method is labour intensive because of the activities associated with the preparation of the measuring circuit (including posi- tioning and calibration of microphones). However, it is particularly useful when it is necessary to identify areas in machines with high vibration activity or assign a share in the emission of sound power to individual machine functional components. This is essential especially when analysing the applicability of various noise protection measures and determining their effectiveness. Therefore, the inversion method for analysing vibroacoustic processes in a machine helps in designing effective technical measures reducing operators' exposure to noise emitted by the machine.

\section{REFERENCES}

1. Wyższy Urząd Górniczy [State Mining Authority]. Stan bezpieczeństwa i higieny pracy w górnictwie w 2010 r. [Occupational safety and health condition in mining industry in 2010]. Katowice, Poland: Wyższy Urząd Górniczy; 2011.

2. Szary M, Chugh YP, Hirschi J. Noise variability in underground room and pillar coal mines. International Journal of Occupational Safety and Ergonomics (JOSE). 2011;17(3): 301-8. Retrieved April 12, 2013, from: http://www.ciop.pl/44615.

3. Sensogut C. Occupational noise in mines and its control-a case study (Letter to editor). Polish Journal of Environmental Studies. 2007;16(6):939-42. Retrieved April 12, 2013, from: http://www.pjoes. com/pdf/16.6/939-942.pdf.

4. Sensogut C, Cinar I. An empirical model for the noise propagation in opencast mines - a case study. Applied Acoustics. 2007;68(9):1026-35.

5. Afeni TB. Osasan SK. Assessment of noise and ground vibration induced during blasting operations in an open pit mine-a case study on Ewekoro limestone quarry, Nigeria. Mining Science and Technology (China). 2009;19(4):420-4.

6. Wyższy Urząd Górniczy [State Mining Authority]. Stan bezpieczeństwa i higieny pracy w górnictwie w 2011 r. [Occupational safety and health condition in mining industry in 2011]. Katowice, Poland: Wyższy Urząd Górniczy; 2012. 
7. Wyższy Urząd Górniczy [State Mining Authority]. Choroby zawodowe [Occupational diseases]. Retrieved April 12, 2013, from: http://www.wug.gov.pl/index. php?statystyki/choroby_zawodowe.

8. Engel JR, Kosała K. Ryzyko zawodowe związane z narażeniem na hałas na wybranych stanowiskach pracy w kopalniach surowców mineralnych [Noise-related occupational risk at selected workstations in open pit mines of mineral raw materials]. Bezpieczeństwo Pracy. 2005;(10):6-9. In Polish, with an abstract in English. Retrieved April 12, 2013, from: http:// www.ciop.pl/17123.

9. Engel JR, Kosała K. Sources of vibroacoustic hazards in open-pit mines of mineral raw materials. Archives of Acoustics. 2007;32(2): 251-62.

10. Engel Z, Engel JR, Kosała K. Procesy wibroakustyczne. Źródła, badania, analiza [Vibroacoustic processes. Sources, tests, analysis]. Kraków, Poland: AGH; 2009.

11. Engel Z, Piechowicz J, Stryczniewicz L. Podstawy wibroakustyki przemysłowej [Elements of industrial vibroacoustics]. Kraków, Poland: AGH; 2003.

12. Engel Z, Piechowicz J, Pleban D, Stryczniewicz L. Hale przemysłowe, maszyny i urządzenia-wybrane problemy wibroakustyczne [Industrial halls, machines and devices-selected vibroacoustic problems]. Warszawa, Poland: CIOP-PIB; 2009.

13. Engel Z, Piechowicz J, Pleban D, Stryczniewicz L. Minimalizacja przemysłowych zagrożeń wibroakustycznych. Poradnik [Minimizing industrial vibroacoustic hazards. A guide]. Warszawa, Poland: CIOP-PIB; 2005.

14. Engel Z, Pleban D, Stryczniewicz L. Inversive method of determination of emission sound pressure levels for the purposes of the acoustic assessment of machines. In: Proceedings of the 8th International Congress on Sound \& Vibration (ICSV8). Hong Kong, China: Department of Mechanical Engineering, Hong Kong Polytechnic University; 2001. p. 1607-14.

15. Engel Z, Pleban D, Stryczniewicz L. Investigation of emission sound pressure using inversive method. Archives of Acoustics. 2002;27(4):277-90.

16. Engel Z, Stryczniewicz L, Piechowicz J. Zastosowanie metody inwersji do wyznaczania cząstkowych mocy akustycznych maszyn [Application of the inversion method for the determination of partial acoustic powers of machines] In: Materiały z Otwartego Seminarium z Akustyki. Gliwice, Poland: Polskie Towarzystwo Akustyczne - Oddział Górnośląski; 2003. p. 70-3.

17. Pleban D. Experimental modelling and research on vibroacoustic phenomena in machines. Archives of Acoustics. 2004; 29(2):219-33.

18. Pleban D, Engel Z, Stryczniewicz L, Piechowicz J. Experimental tests on vibroacoustic phenomena in machinery. GESTS International Transactions on Acoustic Science and Engineering. 2004;2(1):49-59.

19. Pleban D, Engel Z, Stryczniewicz L. Investigation of emission sound pressure levels using parameters of substitute models of machines. GESTS International Transactions on Acoustic Science and Engineering. 2005;3(1):47-54.

20. Stryczniewicz L, Piechowicz J. Inwersyjna metoda modelowania przemysłowych źródeł dźwięku [The inversion method for modelling of industrial sound sources]. In: Materiały XXXIV Zimowej Szkoły Zwalczania Zagrożeń Wibroakustycznych. Gliwice, Poland: Polskie Towarzystwo Akustyczne - Oddział Górnośląski; 2006. p. 165-170.

21. Pleban D. Acoustic modelling of machines using the inversion method for the purposes of the acoustic assessment of machines. Archives of Acoustics. 2007;32(2):321-7.

22. Pleban D. Acoustic modelling of machines using the inversion method. In: Proceedings of the 14th International Congress on Sound \& Vibration (ICSV14) [CD-ROM]. Auburn, AL, USA: International Institute of Acoustics and Vibration; 2007.

23. Stryczniewicz L, Piechowicz J. Experimental results of the inversion method application in industrial conditions. In: Proceedings of the 2nd International Conference on Experiments/Process/System Modeling/ Simulation \& Optimization [CD ROM]. 
Patras, Greece: Chemical Engineering Department, University of Patras; 2007.

24. Stryczniewicz L, Piechowicz J. Zastosowanie metody inwersji w warunkach przemysłowych [Application of the inversion method in industrial conditions]. In: Materiały VII Konferencji WibroTech [CD-ROM]. Kraków, Poland:

Wydawnictwo Wydziału Inżynierii

Mechanicznej i Robotyki; 2006. p. 35-42. 